\title{
Epistemologia da Imagem: o concreto, o abstrato e a metáfora das imagens da organização
}

Epistemology Image: concrete, abstract and images metaphor of the organization

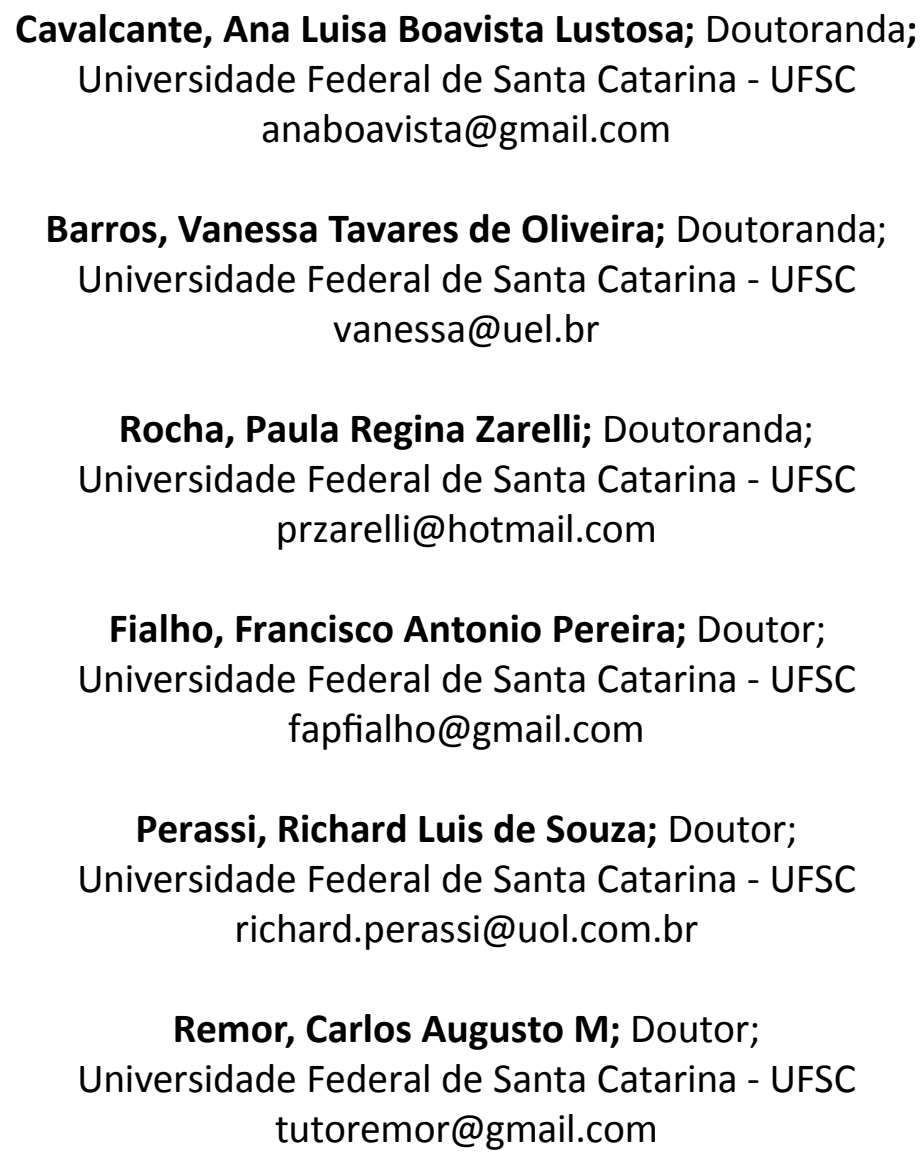

\section{RESUMO}

O presente trabalho visa, a partir da reunião de conceitos e definições sobre imagem, discernir sobre a, intitulada por Joly (1996, p.9), "civilização da imagem". Essas imagens que nos "propõem mundos ilusórios e perceptíveis" que nos fazem deslocar sem sair do lugar. Imaginações, representações que para cada um são diferentes abstrações e que se concretizam de formas distintas. Entre a abstração e a concretização exemplificam-se ideias que, por muitas vezes, ficam em uma tênue fronteira entre os dois conceitos. Ora a abstração concretiza-se, ora o concreto se "desmancha no $\mathrm{ar}^{\text {"1. }}$. Ao final, o artigo trata das imagens da organização em que a metáfora assume um papel na criação do conhecimento. A imagem e a metáfora são vistos como ferramentas de aprendizagem, ou como partes instrumentais do processo de busca do conhecimento.

Palavras-chave: imagem, epistemologia, metáforas da organização.

\section{ABSTRACT}

The present paper from the meeting of concepts and definitions about the image, to discern entitled by Joly (1996, p.9), "culture of images." Such images that "propose illusory worlds and perceptible" that make us go without leaving your seat. Imaginings, representations that are different for each and 
abstractions are realized in different ways. Between abstraction and implementation examples are ideas that, often, are in a tenuous border between the two concepts. But the abstraction becomes concrete, the concrete is sometimes "melts into air." Finally, the article deals with images of the organization that metaphor plays a role in knowledge creation. The image and metaphor are seen as learning tools or as instrumental parts of the process of seeking knowledge.

Key Words: image, epistemology, metaphors of the organization.

\section{Introdução}

A generalização da utilização das imagens pode nos encarregar de decifrar, interpretar, produzir ou apenas contemplar. As imagens podem nos apresentar ameaçadoras por estarmos em um paradoxo em que, por um lado, a leitura das imagens nos parece natural, sem a necessidade de aprendizado, mas que por outro, tem-se a impressão que há sofrimento, mais inconsciente do que consciente, em frente a certa manipulação a partir de imagens em códigos secretos que "zombam da ingenuidade de muitos". (JOLY, 1996, p. 10).

Em Platão, a imagem imita, engana, é reflexo, sombra. "Em primeiro lugar as sombras, depois os reflexos que vemos nas águas ou na superfície de corpos opacos, polidos e brilhantes e todas as representações do gênero". ${ }^{2}$ Em Aristóteles, ela educa.

Um mínimo de iniciação de análise de imagens colaboraria para escapar da impressão de passividade e até de intoxicação e permitir a percepção por meio de uma leitura natural da imagem em termos de convenções, de história e de cultura mais ou menos interiorizadas. (JOLY, 1996).

\section{Imagens: conceitos, definições e significados}

São inúmeros os significados da palavra imagem que uma simples definição se torna complexa. O que há de comum em um desenho animado, um filme, uma fotografia, uma imagem mental? Compreende-se que cada uma dessas representações tem uma indicação e que mesmo não remetendo diretamente ao campo visual, empresta-Ihe traços do visual. Uma imagem depende de uma produção individual: imaginária ou concreta, a imagem passa por alguém que a produz ou a reconhece. (JOLY, 1996).

Uma imagem não é aquilo que se vê, mas a maneira como se vê. Não é a projeção, mas o projetor. Uma imagem é dada pela perspectiva imaginativa e só pode ser percebida pelo ato de imaginar. (CASEY, 1974 e HILLMAN, 1983a, p. 28.)

Noções complexas e contraditórias são associadas ao termo "imagem". Estas vão da sabedoria à diversão, da imobilidade ao movimento (JOLY, 1996, p.17). "Por toda parte no mundo o homem deixou vestígios de suas faculdades imaginativas sob a forma de desenhos, nas pedras, dos tempos mais remotos do paleolítico à época moderna." ${ }^{3}$ Tais desenhos destinavam-se a transmitir mensagens e muitos deles originaram as escritas.

No Renascimento, a separação da representação religiosa da representação profana se origina no surgimento dos gêneros pictóricos. (JOLY, 1996, p.18). Nas artes, a noção de imagem vinculase à representação visual: afrescos, pinturas, iluminuras, ilustrações, desenhos, gravuras, filmes, fotografias. Para Joly (1996, p.19), a imagem é instrumento de comunicação. A imagem se assemelha ou se confunde com o que representa.

Representação, em Japiassú \& Marcondes (2001), vem do latim repraesentatio e

é a operação pela qual a mente tem presente em si mesma uma imagem mental, uma idéia ou um conceito correspondendo a um objeto externo. A função de representação é exatamente a de tornar presente à consciência a realidade externa, tornando-a um objeto da consciência, e estabelecendo assim a relação entre a consciência e o real. 
Deste modo, uma imagem pode representar algo que pertence a uma coletividade, assim como a ideia que uma pessoa tem de uma coletividade. Nas figuras 1 e 2 a proximidade entre a imagem e uma linguagem gestual é percebida. (FRUTIGER, 1999, p.84). Tais abstrações de diferentes épocas e locais representam mulheres dançando em distintos contextos culturais.

Figura 1 - Pintura rupestre - Austrália Ocidental.

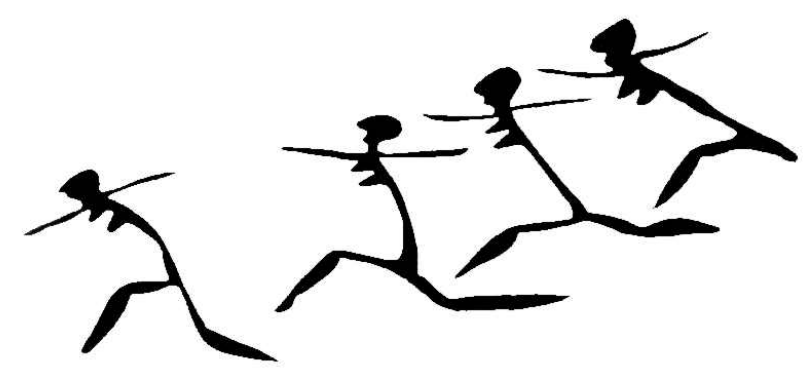

Fonte: Laing \& Wire (1996) $)^{5}$.

Figura 2 - Heitor dos Prazeres, Frevo, $1966 .{ }^{4}$

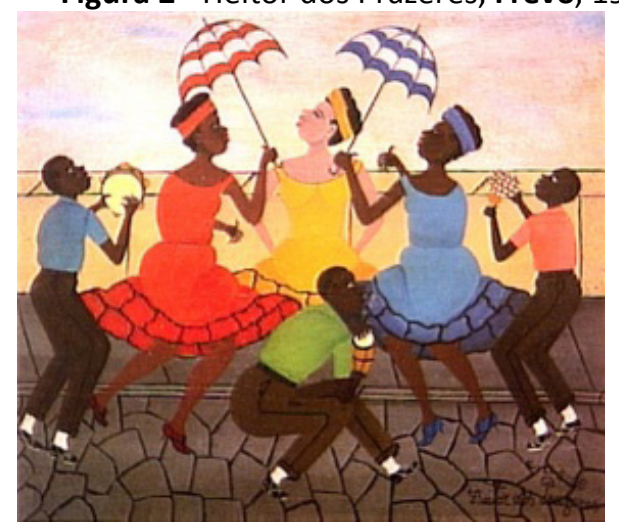

Fonte: <www.itaucultural.org >. Acesso em: 20/09/2010.

Em Japiassú \& Marcondes (2001), a noção de representação geralmente define-se por analogia com a visão e com o ato de formar a imagem de algo.

Para Piaget (1978) apud Campos \& Souza (2000, p.5) a

\begin{abstract}
representação pode significar tanto uma imagem mental (um símbolo concreto), quanto um conceito (abstrato). Há uma continuidade entre formas perceptivas e representações figuradas e as imagens visuais necessitam de esquemas motores e perceptivos prévios, adquiridos pela vivência [...], resultando em um novo tipo de esquema avançado, que é a abstração. $O$ termo representação é, portanto, usado em dois sentidos diferentes, ou seja, como pensamento [...] e como imagem mental ou recordação-imagem.
\end{abstract}

Representar é tornar presente. Isto ocorre pela presença de um signo que é, para Pierce (1972) apud Pereira (2003, p.46) algo que representa alguma coisa para alguém. O signo promove a comunicação entre as pessoas, entre pessoas e objetos e entre pessoas e locais e possui um objetivo, uma intenção e um significado. Os signos surgem da necessidade humana de representar algo para melhor compreender, interpretar e analisar. A imagem como signo visual faz parte da linguagem não verbal. Segundo Guimarães (2002), está multiplicada pela "era da produtibilidade do informacional do visível", tornando-se "onipresente em um mundo tomado por telas de toda ordem". A propagação da imagem "copiada, clonada e editada", perde os atributos originais, pois as imagens perdem a transcendência, ou seja, "o poder de fabulação", pois sendo simuladas, "perdem seu vínculo sensível 
com o mundo". (GUIMARÃES, 2002). A identidade perdida da imagem quando fragmentada pelo excesso ou repetição de códigos.

O ser humano elabora códigos, que é um sistema convencional de signos e os utiliza na transmissão de mensagens. Utiliza a linguagem como ferramenta. Esta é "um sistema de signos convencionais que pretende representar a realidade e que é usada na comunicação humana." (JAPIASSÚ \& MARCONDES, 1996).

A capacidade do ser humano de criação de imagens para si próprio e para outros tem sido, segundo Flusser (2007, p.161), "um dos temas das reflexões filosóficas e teológicas".

Uma "singular capacidade de distanciamento do mundo dos objetos e do recuo para a subjetividade" é para Flusser (2007, p.163) a imaginação que complementa sendo a capacidade de se tornar sujeito de um mundo objetivo. Os meios contemporâneos transformam imagens em modelos de comportamento e fazem dos homens objetos. "Mas os meios podem funcionar de maneira diferente a fim de transformar as imagens em portadoras e os homens em designers de significados" (FLUSSER, 2007, p.159)

Para Oliveira (2005, p.23), o parâmetro da funcionalidade pode contribuir com o estudo sobre imagem. Analisar as finalidades que podem ter as imagens significa verificar as funções (Como funciona? Para que serve?). As funções de uma imagem podem se alterar no tempo e no espaço. $\mathrm{O}$ que em determinado contexto cultural teve funções religiosas ou persuasivas podem, em outro local, deixar de tê-las, mesmo que continuando com as funções estéticas e simbólicas. No filme "Os Deuses Devem Estar Loucos" 6 uma garrafa que para o piloto era algo que não tinha mais valor, era para os integrantes de uma aldeia isolada um estranho artefato, um presente dos deuses, algo com uma função simbólica intrigante e com muitos usos a serem descobertos. As igrejas barrocas de Ouro Preto, repletas de peças destinadas aos usos ritualísticos, possuem relevantes obras de arte sacra, hoje praticamente funcionam como museus. Imagens que interessam não somente aos religiosos, como também ganham atenção de estudiosos ou de público em geral.

Uma imagem é um produto homogêneo, completo, total, com um significado próprio, uma "expressão condensada da situação psíquica". (AVENS, p. 50.).

A imagem mental é uma impressão que temos de algo. "Uma imagem é contexto, disposição, cenário". Deste modo, não pode estar somente diante dos olhos ou do olho da mente. É algo em que se entra e pelo qual se é abraçado. "As imagens nos prendem". (HILLMAN, 1978, p. 159.).

Na psicologia junguiana, a palavra "imagem" é um termo poético e vê as coisas somente de maneira indireta, não é equivalente à memória, à lembrança da imagem, a um reflexo de um objeto ou a uma percepção. (AVENS, p. 50.).

Em "A Tempestade", comédia de Shakespeare (1564-1616), o personagem Próspero mantinha sob seu controle a percepção dos demais. Em lugar da imagem desolada da ilha onde se encontravam, enxergavam uma bela paisagem habitada por seres amigáveis. "A filha de Próspero, Miranda, não contendo a emoção diante das ilusões orquestradas pelo pai, exclamou: - Que admirável mundo novo!". Essa expressão passou a significar uma percepção equivocada ou alterada e sob influência de outro. Nota-se o aspecto contido de ingênua ironia, pois supõe que alguém possa ter o controle do real estado das coisas, enquanto os outros permanecem iludidos. (CAMPOS \& SOUSA, 2000). No filme "La Vita è bella"7 de Roberto Benigni (1997) o pai, ao poupar o filho do sofrimento, se empenha em esconder o terror e os perigos que os cercam, fantasiando um jogo.

Imagens podem representar não apenas coisas, mas também noções ligadas a essas coisas ou conceitos. Para Flusser (2007, p.152), uma imagem é uma mensagem: ela tem um emissor que procura por um receptor. Essa procura depende do transporte já que as imagens são superfícies. Se a imagem está em uma caverna em Lascaux, não será transportável, o receptor deve ir até ela. No entanto, se é capturada podem ser reproduzidas, alcançando cada receptor isoladamente. "As imagens se tornam cada vez mais transportáveis e os receptores cada vez mais imóveis, isto é, o espaço político se torna cada vez mais supérfluo". (FLUSSER, 2007, p.153). É uma característica dos tempos atuais e não apenas da nova técnica. Trata-se de uma revolução cultural.

Flusser (2007, p.156), também aponta para a "inflação de imagens" ou "aceleração da sequência de imagens". As imagens são programadas para reduzir ao mínimo toda crítica por parte do receptor. 
Há também as imagens que inspiram a reflexão, o discernimento sobre algo.

Da imaginação (ideação) à representação da imagem, Descartes chama de idéias da imaginação as idéias produzidas por nossa mente (a quimera, a sereia), que não correspondem a objetos da experiência. Em Kant, a imaginação é uma faculdade da consciência que unifica e sintetiza a diversidade dos dados da intuição, constituindo assim a condição de possibilidade do conhecimento. (JAPIASSÚ \& MARCONDES, 2001). Distingue-se: imaginação reprodutiva, que produz imagens daquilo que percebemos; e imaginação criadora, que produz imagens do que jamais percebemos.

\section{Imagem: o concreto e o abstrato}

Desde o século XVIII, cristalizam-se, entre outros, dois pólos referenciais, conforme indica Korfmann, a respeito da qualidade artística: o concreto e o abstrato. Ambos são encontrados em diversas formas de representação. Este ainda exemplifica que o pintor e escritor russo Wassily Kandinsky, conhecido como pintor abstrato, foi também escritor de poesia concreta e autor de peças de teatro em que a linguagem cênica e textual serve para evocar sonoridades e visualidades específicas, apelando para o conjunto dos sentidos, a sinestesia.

Em Pollock, as formas abstratas e lineares encontram o "automatismo psíquico dos dadaístas e surrealistas"(CAVALCANTI, 1966, p.179 apud GUIMARÃES, 2002, p.118).

Figura 3 - Untitled No. 3, Jackson Pollock

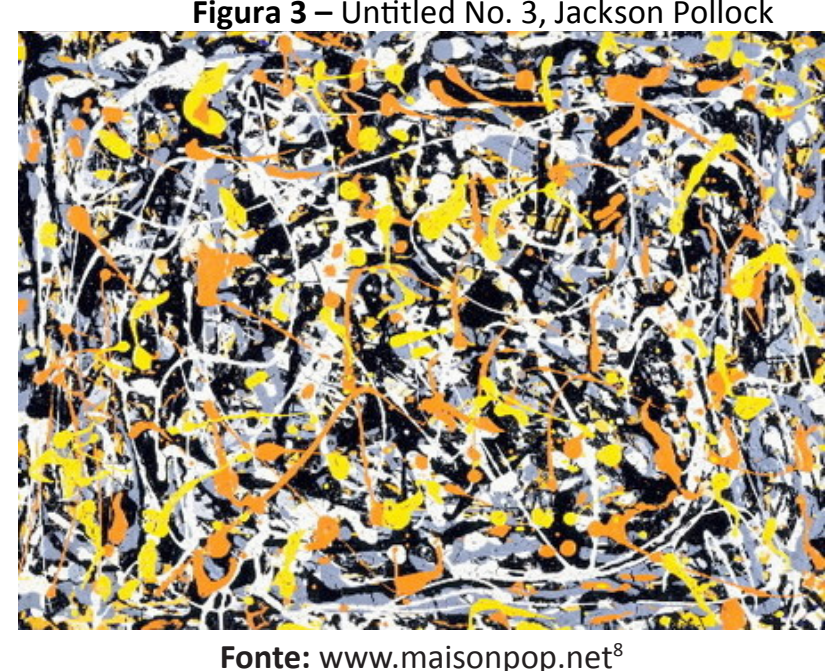

Figura 4 - Composição Clara, 1942, Wassily Kandinsky.

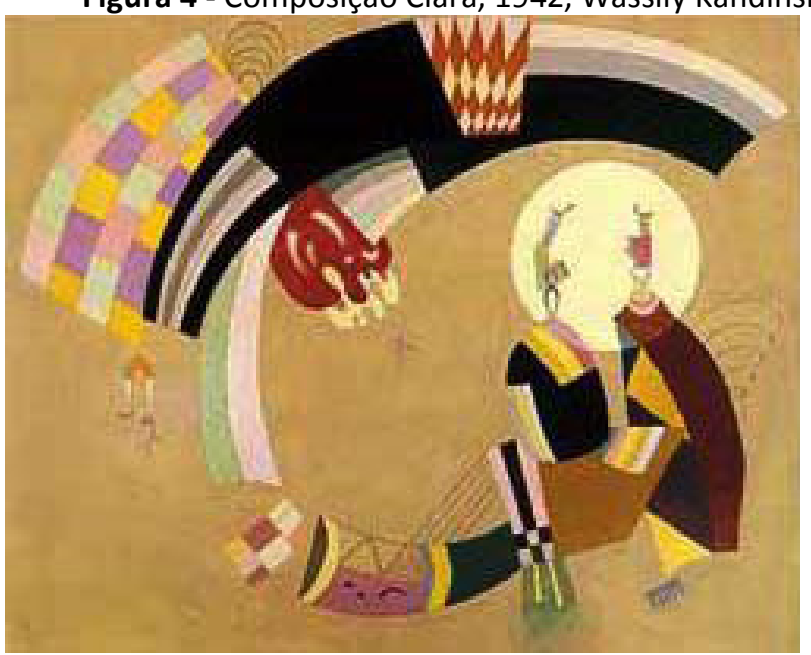

Fonte: MACVIRTUAL / USP ${ }^{9}$ 
Japiassú \& Marcondes (2001) considera Abstrato, do latim abstractus, como

separado, independente de suas determinações concretas e acidentais. Uma idéia abstrata é aquela que se aplica à essência considerada em si mesma e que é retirada, por abstração, dos diversos sujeitos que a possuem. Ex.: a brancura, a sabedoria, o orgulho etc. [...]. É também o produto da abstração que consiste em analisar o real, mas considerando separadamente aquilo que não é separado ou separável. Oposto a concreto.

Abstração ${ }^{10}$ para Japiassú \& Marcondes (2001) corresponde à "operação do espírito que isola para considerá-lo à parte. Um elemento de uma representação, o qual não se encontra separado na realidade". Abstração é:

o processo pelo qual o espírito se desvincula das significações familiares do vivido e do mundo das percepções para construir conceitos. Na linguagem corrente, as palavras "abstrato" e "abstração" possuem certa conotação pejorativa. Assim, dizemos de alguém que "ele se perde em abstração", dá preferência às "idéias abstratas" e não se atém aos "fatos concretos". Notemos o sentido paradoxal da expressão "fazer abstração de", que significa "afastar, não se levar em conta". Há a idéia de separação (algo é isolado de seu conjunto), mas com o objetivo de não se ocupar dele. No sentido filosófico, quando algo é isolado por abstração, é para se fixar nele a atenção.

Na animação da música Túnel do Tempo ${ }^{11}$ de Frejat, percebe-se que a abstração da letra retrata e concretiza-se em outra ideia a partir da imaginação. Diversos conceitos a partir de abstrações são apreendidos: amor, saudade, tristeza, amizade, felicidade. Estes se concretizam em imagens em movimento que inspiram novas imaginações.

Concreto do latim concretus, em Japiassú \& Marcondes (2001) apresenta-se de várias formas, a saber:

1. Para o senso comum o concreto é tudo aquilo que é dado pela experiência sensível, seja externa (as diversas sensações que qualificam um objeto), seja interna (as emoções de medo, um sonho etc.).

2. Por oposição a abstrato, o concreto é aquilo que é efetivamente real ou determinado em sua totalidade. Portanto, é o que constitui a síntese da totalidade das determinações: "O concreto é concreto porque é a síntese de múltiplas determinações, portanto, a unidade da diversidade" (Marx).

3. Em seu sentido lógico, o concreto diz respeito aos termos que designam seres ou objetos reais: Pedro, meu cachorro etc.

4. Para a filosofia existencialista, o concreto designa a existência humana, a realização humana vivida na sociedade e na história, fazendo com que cada homem viva em situação sempre singular: "concreto é o homem neste mundo" (Sartre). Oposto a abstrato.

Ressalta-se a tênue fronteira entre o concreto e o abstrato. Opostos, antagônicos, tais conceitos se complementam e revelam aproximação e afastamento. No discernimento entre os conceitos tem-se a seguir o exemplo das metáforas da imagem da organização.

\section{Imagens da organização}

O entendimento da imagem sob o ponto de vista do concreto, aplicado à gestão, é dado por Perassi (2002) quando afirma que a teoria administrativa, como objeto formal, propõe um conjunto de enunciados próprios baseado em princípios científicos e filosóficos. Como objeto material, a administração é tomada como tecnologia, ciência e filosofia aplicadas e, também, como arte. Como 
ciência, a administração integra as ciências sociais. Mas, como filosofia aplicada ou como arte, o fenômeno administrativo escapa ao controle da análise científica, por expressar em sua ocorrência elementos da sensibilidade, da subjetividade e da intuição humanas. Em síntese, a amplitude da arte administrativa não é totalmente apreendida pelo reducionismo científico.

Neste sentido, tem-se a imagem e a metáfora como "instrumentos" de aprendizagem, ou como partes instrumentais do processo de buscar o conhecimento. Na ótica da gestão, Morgan (1996) trabalha as imagens da organização em que a metáfora assume um papel na criação do conhecimento e, "por ser a metade do caminho entre o não inteligível e o lugar comum", fazendo alusão a Aristóteles. Este lugar comum assume o papel do concreto quando o autor trabalha as metáforas subsequentes como uma forma de imaginar a organização, as situações adequadas do paradigma e as limitações ao qual o enfoque não funciona adequadamente.

A primeira metáfora trata da imagem da organização como máquina. Esta metáfora é tanto mais adequada: (a) quando existe uma tarefa contínua a ser desempenhada; (b) o ambiente é suficientemente estável para assegurar que os produtos oferecidos sejam apropriados; (c) se quer produzir sempre exatamente o mesmo produto; (d) a precisão é a meta; e (e) as partes humanas da máquina são submissas e comportam-se como foi planejado que façam.

As limitações correntes desta metáfora dizem respeito à: (a) criação de formas organizacionais que tenham grande dificuldade em se adaptar a circunstâncias de mudança; (b) desembocar em um tipo de burocracia sem significado e indesejável; (c) ter consequências imprevisíveis e indesejáveis à medida que os interesses daqueles que trabalham na organização ganhem precedência sobre os objetivos que foram planejados para serem atingidos pela organização; (d) ter um efeito desumanizante sobre os empregados, especialmente sobre aqueles posicionados em níveis mais baixos da hierarquia organizacional.

A figura 6, cena extraída do filme "Tempos Modernos" de Chaplin ilustra esta metáfora em que o personagem tenta sobreviver em meio ao mundo moderno e ao industrialismo.

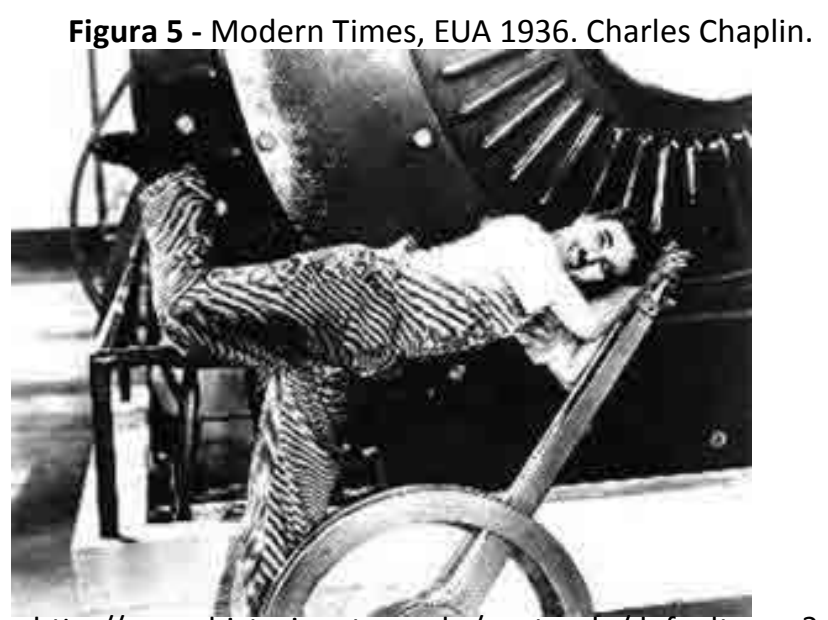

Fonte: Disponível em: http://www.historianet.com.br/conteudo/default.aspx?codigo=181> Acesso em: 21 SET 2010.

Outra metáfora da imagem da organização é a orgânica. Esta metáfora trata da ênfase colocada na compreensão das relações entre as organizações e os seus ambientes, bem como do pressuposto que a administração das organizações com frequência pode ser melhorada por meio da atenção sistemática das necessidades que precisam ser satisfeitas, caso a organização deva sobreviver. Ao identificar diferentes espécies de organização, fica-se alertado o fato de que na organização sempre se tem um conjunto de opções, põe em evidência a virtude das formas orgânicas de organização no processo de inovação, contribui à teoria e à prática do $\mathrm{DO}$, especialmente através do enfoque contingencial e através de uma orientação sobre ecologia e relacionamentos interorganizacionais.

Morgan (1996) afirma como limitações da metáfora orgânica o fato de que se é levado a ver as organizações e seus ambientes de maneira muito distante do concreto, além de uma suposição da 
unidade funcional e o perigo da metáfora transformar-se em uma ideologia.

A metáfora do cérebro busca contribuir para a compreensão da aprendizagem organizacional e às suas capacidades de auto-organização. As organizações inovadoras devem ser planejadas como sistemas de aprendizado que colocam ênfase especial em estar abertas à investigação e autocrítica e a administração estratégica pode ser planejada para facilitar o aprender a aprender. Também oferece meios em que se pode ir além da limitada racionalidade que caracteriza muitas organizações no presente e oferece meios valiosos de pensar sobre como desenvolvimentos na computação e outras tecnologias em micro processamento podem ser utilizados para facilitar novos estilos de organizações.

Os perigos desta imagem podem residir em não se levar em conta importantes conflitos entre os requisitos da aprendizagem e auto-organização, por um lado, e das realidades de poder e controle, por outro. Desde que qualquer movimento no sentido da auto-organização deva ser acompanhado por importantes mudanças de atitudes e valores, as realidades do poder podem ser reforçadas pela inércia que vem das suposições e crenças existentes.

A imagem da organização como cultura dirige a atenção para o significado simbólico ou mesmo mágica da maioria dos aspectos racionais da vida organizacional. Nesta metáfora, a organização repousa sobre sistemas de significados comuns e, portanto, em esquemas interpretativos que criam e recriam aquele sentido, oferecendo a metáfora um novo foco e via de acesso para a criação da ação organizacional. Isto ainda abre caminho para a reinterpretação de muitos conceitos e processos da administração tradicional. Reinterpretar a natureza e o significado das relações das organizações com o ambiente e contribuir para a compreensão da mudança organizacional. A única limitação desta metáfora é que existe uma importante dimensão de poder subjacente ao processo de representação que a metáfora da cultura nem sempre ressalta como seria desejável. Quando isso é levado em conta, a metáfora da cultura torna-se impregnada de sabor político.

Os principais enfoques da metáfora política ajudam a encontrar uma forma de suplantar as limitações da idéia de que as organizações são funcionalmente sistemas integrados. Esta metáfora politiza a compreensão do comportamento humano nas organizações, e também encoraja o reconhecimento das implicações sociopolíticas dos diferentes tipos de organizações e dos papéis que estas desempenham na sociedade.

As lacunas da metáfora política é que podem exibir um comportamento político daquilo que se vê, olhar intenções ocultas, mesmo que não existam e discute até que ponto as implicações do pluralismo são meramente superficiais.

A prisão psíquica é apresentada por Morgan (1996) como metáfora no seguinte contexto:

- Apresenta um conjunto de perspectivas para a exploração do significado oculto dos nossos mundos tidos como verdadeiros;

- Encoraja-se na procura para descobrir os processos inconscientes e respectivos modelos de controle que aprisionam as pessoas em esquemas insatisfatórios de existência;

- O conhecimento das organizações tem sido racionalizado em excesso, tanto nos comportamentos como nas explicações (sombras da racionalidade);

- Bases éticas da organização ao reforçar a visão de que a organização é humana no seu sentido mais completo;

- Identificam-se muitas das barreiras situadas no caminho da inovação e mudança.

Este contexto é criticado à medida que enfatiza a compreensão de modelos inconscientes de comportamento e controle, requerendo levar em conta ideologias mais explícitas que controlam e moldam a vida organizacional. Pode ser criticada por enfatizar excessivamente o papel dos processos cognitivos de criar, manter e mudar as organizações e a sociedade, frequentemente encoraja especulações e críticas utópicas e desperta o espectro de um mundo orwelliano em que seria tentado gerir mente de outras pessoas.

A constatação de que muitos problemas sociais e organizacionais pouco provavelmente podem ser resolvidos em partes é trazida pela metáfora do fluxo. Há um aspecto autorregulador em relação a muitos problemas contemporâneos que só pode ser atacado fazendo-se referência à lógica 
que produz enquanto problemas. Neste ínterim, as abordagens geradas por este tipo de raciocínio são muito idealistas e uma completa compreensão da lógica da mudança sempre depende de uma percepção tardia, na visão limitada da metáfora.

Como última metáfora, o autor mostra um caminho para criação de uma teoria organizacional para os explorados. Fornece as bases para uma crítica verdadeiramente radical da organização e das teorias. Não obstante, se a dominação vista como parte de uma conspiração social ou como a responsabilidade de alguns indivíduos, as consequências latentes são atribuir culpa, levantar defesas e ocultar os problemas fundamentais. Perigo ainda de que, ao se afirmar uma equivalência entre dominação e organização, corre-se o risco de não visualizar a noção de que formas não dominantes de organização sejam possíveis. A metáfora articula tão somente um tipo extremo de ideologia de esquerda, servindo para inflamar as chamas da estrutura radical de referência, contribuindo, assim, para aumentar as dificuldades dos gerentes em um mundo turbulento.

\section{Conclusão}

$\mathrm{Na}$ busca de significação entre o concreto e o abstrato, percebe-se o não estabelecimento de uma única ideia sobre o conceito: imagem.

O paradoxo entre uma leitura natural do que está sendo percebido, visualizado e as imagens manipuladas impregnadas de conceitos nos leva ao discernimento sobre as funções da imagem em um determinado tempo e espaço. Os cartazes construtivistas russos que, na "construção de um novo ideal", utilizavam diferentes meios de persuasão das massas como a fotografia, a tipografia, são exemplos da manipulação. É a imagem objeto que transforma, a partir de modelos de comportamento, homens em objeto. Tais imagens transportáveis ou não e receptores móveis ou imóveis estão interagindo de modo a causar alterações na função da imagem de acordo com as questões culturais de cada época.

As metáforas da imagem da organização apresentadas foram formas de imaginação. No paradigma e suas limitações abstrai-se para compreender o concreto.

\section{Notas}

1"tudo que é sólido desmancha no ar", Marx apud Berman M. Tudo que é sólido desmancha no Ar. A aventura da modernidade. Trad: C. F. Moiséis e A. M. L. Ioriatti. SP: Cia. das Letras, 1986.

2Platão. La République. Trad. É. Chambry. Paris: Les Belles Letres, 1949.

3..-J. Gelb. Pour une histoire de l'écriture. Paris: Flammarion, 1973.

${ }^{4}$ Prazeres, Heitor dos Frevo, 1966 óleo sobre tela, c.i.d. 46 x $55 \mathrm{~cm}$. Reprodução fotográfica Leondino A. Kubis. Acesso: 20/set/2010. <http://www.itaucultural.org.br/aplicexternas/enciclopedia_ic/index. cfm?fuseaction=artistas_biografia\&cd_verbete=2010>

${ }^{5}$ Laing, J. \& Wire, D. Enciclopedia de Signos e Símbolos, Mexico: Ediciones GG, 1996).

${ }^{6}$ No original The Gods Must Be Crazy, filme de 1980, escrito e dirigido por Jamie Uys. Conta a história de Xixo, um bosquímano do Kalahari cuja tribo não tinha contato ou conhecimento do mundo além desta. <http:// pt.wikipedia.org/wiki/Os_Deuses_Devem_Estar_Loucos> Acesso em 22 ago 2010.

${ }^{7}$ Estúdio Melampo Cinematografica, Itália, 1997.

${ }^{8}$ Disponível em: <http://www.maisonpop.net/spip.php?article991> Acesso em 23 set 2010.

${ }^{9}$ Disponível em: http://www.macvirtual.usp.br/mac/templates/projetos/seculoxx/modulo1/abstracionismo/ kandinsky/obras.html Acesso em: 20 set 2010.

${ }^{10}$ Latim: abstractio, de abstrahere: separar de):

${ }^{11}$ <http://www.youtube.com/watch?v=QOnoTUP9EpA\&feature=fvw>. Animação da empresa Estúdio

Consequência [www.consequencia.com]. Acesso em 27 ago 2010.

\section{Referências}


Cavalcante, Ana L.B.L.;Barros, Vanessa T. de O.; Pereira,Francisco A.F.; ; Perassi, Richard L. S.; Remor, Carlos A.M;

AVENS, R. Imaginação é Realidade, Petrópolis: Ed.Vozes, 1993.

CAMPOS, P. M. \& E., SOUZA, R. C. F. Imagem mental e representação social: estudo de caso. 1.0 Congresso Internacional de Arquitetura e Psicologia - FAU/UFRJ. Ago 2000. Disponível em: <http:// www.arq.ufmg.br/rcesar/Imagem\%20mental.pdf.> Acesso em: 20 ago 2010.

GUIMARÃES, C. O novo regime do visível e as imagens digitais. Estação imagem: desafios. VAZ, P. B. \& NOVA, V. C. (Orgs.), Belo Horizonte: Ed. UFNG, 2002.

HILLMAN, J. Further Notes on Images, Spring Journal, 1978.

JOLY, M. Introdução a Análise da Imagem. Coleção: Arte \& Comunicação. São Paulo: Edições 70, 1996.

KORFMANN, M. Do concreto e abstrato: August Strindberg e a fotografia experimental, http://www. unigran.br/revistas/interletras/ed_anteriores/n6_n7/textos/concreto_abstrato.pdf. Acesso em: 21 ago 2010.

MORGAN, G. Imagens da organização. BERGAMINI, C.W.; CODA, R. (trad) São Paulo: Atlas, 1996.

OLIVEIRA, S. R. Imagem também se lê, Rio de Janeiro: 2AB, 2005.

PERASSI, R. A estética na gestão organizacional: conhecimento e comunicação. In: II Jornada Cientifíca do Centro-Oeste de Economia e Administração, 2002, Campo Grande. Anais da II Jornada Cientifíca do Centro-Oeste de Economia e Administração. Campo Grande : UFMS, 2002. 